\title{
The Influence of Faith and Religiosity in Coping with Breast Cancer
}

\author{
Nakane $\mathrm{S}^{*}$ and Koch $\mathrm{H}^{2}$ \\ ${ }^{1}$ Psychologist, Brazil \\ ${ }^{2}$ Professor at the Post-Graduation Radiology course at FM/UFRJ, Brazil
}

*Corresponding author: Nakane S, Psychologist, Tel: 5521 997677999, Brazil, E-mail: sanynakane@gmail. com

Citation: Nakane S, Koch H (2017) The Influence of Faith and Religiosity in Coping with Breast Cancer. J Adv Radiol Med Imag 2(1): 103. doi: 10.15744/2456-5504.2.103

Received Date: September 15, 2017 Accepted Date: November 28, 2017 Published Date: November 30, 2017

\begin{abstract}
The study researches the influence of faith and religiosity in coping with breast cancer based on the analysis of spiritual well-being and the association of spirituality/religiosity and its practices with the acceptance of diagnosis, treatment adherence and future prospects for the patient. A descriptive and field research carried out with patients diagnosed with breast cancer resulted in the evident conclusion that faith and religiosity present themselves as the determinant, potent and active factors in their clinical treatments and in their lives.
\end{abstract}

Keywords: Faith; Religiosity; Breast cancer

\section{Introduction}

Starting with the analysis of the innumerous research results from the past few years, coming from different cultures from all over the world, it is undeniable that faith and religiosity play an important part of facing and coping with highly stressful situations and negative emotions. Beliefs and practicing of a religion present as an important factor in leading with sickness and its direct consequences on patients life and family.

Praying stands out on a list of alternative indispensable means in maintaining the well-being of patient's physical and mental health. Another noticeable thing is the fact that these patients, while going through an extensive treatment, maintain social involvement and relationships outside of clinical ambient, considerably raising the level of personal satisfaction.

There are very few doubts when it comes to the positive effect of the faith and religion when coping with sickness. It is shown to help during the treatment, keeping patient's will strong, lowering the stress levels, and raising hope for the positive effects of the treatment and its outcome. The positive effects are not seen only when the sickness has already presented itself, but research has shown that people of faith and religiosity are more responsible when it comes to taking precautionary measures and leading a healthier lifestyle.

This paper is focused on the research of the role spirituality and religion have when facing breast cancer, starting with the analysis of the influence on the spiritual well-being measured by Scale of Spiritual Well-Being (SWBS) and how spirituality and religion are connected to the acceptance of the diagnosis, treatment and patient's future.

Breast cancer involves factors such as biological ones of the endocrine system, reproductive life, behavior, and lifestyle. The global estimate of the cancer diagnosis went from 14 million in 2012, to 19,3 predicting for 2025; while predicting mortality from 8 million in 2012 to 11,4 for 2025 [1].

Worldwide, the breast cancer is the most frequent one and the leading cause of death among women, especially among those of age 40-49. In the USA annually there are 230.000 new cases diagnosed every year and around 40.000 deaths caused by breast cancer. The later the diagnosis is set, the more invasive the treatment and its consequences are [2].

After giving the diagnosis, the possibility of dying is what might make a patient feel vulnerable, anguished, pessimistic, hopelessness and anxious. These matters normally make patients question life, their own worth, and what to do next.

Normally, after breast cancer diagnosis, many questions arise about the potential causes of the illness and potential therapeutic results. At the same time, there's the spirituality/religiosity component. In spite of the pain and the uncertainty, something transcending makes patients fight for the life. 
Specific elements may prove in certain ways that spiritual and religious awakening is directly related to a quality of life, patient's preferences set in their choices, interpretations, and reevaluations [3]. Spirituality/religiosity raises hope and it serves as a buffer when facing the illness, helping patients fight and making them stronger, as advisories of the positive outcome of the treatment.

Women with breast cancer confront many obstacles in their life - physically, socially, emotionally, and spiritually. As soon as possible after the diagnosis has been given, it's important to set the grounds and establish the right therapeutic treatment. This may alleviate the stress caused by doubts and uncertainty about the future.

The factors related to spirituality and religiosity has been related to the adaptation to the diagnosis and the cancer treatment, showing their importance in patient's recovery process and for their health. Facing the illness with religion and spirituality involved is a type of a coping mechanism that should help deal with stressful life events. Nevertheless, the positive or negative outcome of the spiritual/religious influence in leading with stressful life events depends on the way one handles the stressful event and one's personal beliefs [4].

Given all of this, recent growing interest in understanding what potential impact faith/religiosity have in patients diagnosed with life-threatening diseases is impossible to ignore; and how it's connected to therapeutic results and spirituality [5], how much spiritual/religious involvement can be included in clinical treatment [6], and how cancer affects people's perception of patient's life quality and their families [7].

\section{The Method}

This article takes a descriptive approach and a fieldwork based research with previously selected patients diagnosed and in treatment for breast cancer, whose identities have been preserved by specific nomenclature.

For data collecting, individual questionnaires, following the interview script were used, in order to obtain information about patient's life that is relative to this research.

For better analysis and validation of the collected information, the Spiritual Well-Being Scale has been used. SWBS has for its goal to evaluate one's general well-being. The Scale was created by Poulotizan and Ellison in 1982 [8], and it was adapted for Brazilian population by Marques et al. [7].

The Spiritual well-being is defined as a feeling of well-being that one has when there's a purpose that justifies a commitment to something in one's life. The spiritual well-being is considered as the one regarding a union and personal relationship with God or a supreme force [6].

The SWBS consists out of 20 points, 10 that assess the religious well-being (RWB) referencing the God; and the rest existential well-being (EWB), without the religious component. The half of the questionnaire is positive-oriented and the other half on the negative. Each of the 20 questions is answered on the 6-point scale: strongly agree (SA), agree (A), partly agree (PA), partly disagree (PD), disagree (D), and strongly disagree (SD). The positive-oriented questions $(3,4,7,8,10,11,14,15,17,19$ and 20$)$ are scored as following: $\mathrm{SA}=6, \mathrm{~A}=5, \mathrm{PA}=4, \mathrm{PD}=3, \mathrm{D}=2, \mathrm{SD}=1$, the rest, given that are negative-oriented questions, have inverted values $(S A=1, A=2, P A=3, P D=4, D=5, S D=6)$. The total score is a sum of these 20 questions and it may vary from 20 to 120 points. The scores of the two sub-sections are summed up to get the SWBS average.

Paloutzian and Ellison suggest the following point intervals: 20-40 low, 41-99 moderate, 100-120 high [8]. In the sub-sections: 10-20 is considered low, 21-49 moderate, and 50-60 high.

The evaluation study done on the sample group was descriptive, transversal, prospective, aiming to draw a profile of spirituality and religiosity in dealing with breast cancer in patients of the Mário Kroeff Hospital - an institution of reference in cancer treatment, set in the North zone of Rio De Janeiro. The literature sources show that the religion and spirituality prevail by 90\% [7]. Based on this information, the sample group of 138 women with the breast cancer was $99 \%$ reliable, leaving $5 \%$ chance for to the sampling error.

The descriptive analysis presented in the charts with the collected data, expressed by the measures of central (average and median) and dispersion (standard deviation and interquartile range) for numerical data, and by the frequency (n) and percentage (\%) for categorical data, with some illustrative graphics. Statistical analysis was performed by SAS 6.11 software (SAS Institute, Inc., Cary, North Carolina).

The primary statistical analysis was descriptive, presenting collected data in the form of charts or illustrative graphs. Numerical data were presented as the average \pm standard deviation or median and interquartile range (Q1-Q3), the latter for non-Gaussian data, and the categorical data were given in frequency and percentage.

In order to possibly test some connections between the observed variables, univariate methods were applied, such as:

- in the case of the collaboration among groups, the t-test was given to collect an independent sample for numerical data, and the qui-square or Fisher's exact test for categorical data;

- in the association between numerical data, the Pearson correlation coefficient was used. 
The corresponding non-parametric tests were applied in the case of rejection of the normality hypothesis, according to the Shapiro-Wilks test. The criterion for determining significance was 5\%. Statistical analysis was processed by SAS 6.11 software (SAS Institute, Inc., Cary, North Carolina).

\section{Results and the arguments}

\section{Characterization of the sample}

Table 1 provides an overview of the demographic and treatment variables, outlining the general profile of the patients studied. Numerical data were expressed as average, standard deviation, minimum and maximum or medium and interquartile range (Q1 - Q3), and the categorical data present by frequency (n) and percentage (\%).

\begin{tabular}{|c|c|c|}
\hline \multicolumn{3}{|c|}{ Epidemiological and treatment variables } \\
\hline Age (years) & & \\
\hline $\begin{array}{l}\text { average + SD } \\
\text { (minimum - } \\
\text { maximum) }\end{array}$ & $58,8 \pm 12,3$ & $(42-90)$ \\
\hline \multicolumn{3}{|l|}{ Civil Status- $n(\%)$} \\
\hline Married & 12 & 42,9 \\
\hline Single & 5 & 17,9 \\
\hline Divorced & 7 & 25,0 \\
\hline Widow & 4 & 14,3 \\
\hline \multicolumn{3}{|l|}{ Education - $n(\%)$} \\
\hline Illiterate & 3 & 10,7 \\
\hline Incomplete ELEM & 5 & 17,9 \\
\hline Completed ELEM & 4 & 14,3 \\
\hline Incomplete HS & 4 & 14,3 \\
\hline Completed HS & 9 & 32,1 \\
\hline Incomplete UNIV & 2 & 7,1 \\
\hline Completed UNIV & 1 & 3,6 \\
\hline \multicolumn{3}{|l|}{ Occupation - $n(\%)$} \\
\hline Employed & 17 & 60,7 \\
\hline Unemployed & 4 & 14,3 \\
\hline Retired & 7 & 25,0 \\
\hline \multicolumn{3}{|l|}{$\begin{array}{l}\text { Has been diagnosed } \\
\text { for }\end{array}$} \\
\hline average (Q1 - Q3) & 8,5 & $(6-12)$ \\
\hline \multicolumn{3}{|l|}{ Stage - $n(\%)$} \\
\hline Pre-op & 19 & 67,9 \\
\hline Post-op & 9 & 32,1 \\
\hline
\end{tabular}

\section{The description of the spiritual well-being questionnaire - the SWBS scale}

Table 2 provides the descriptive (average, standard deviation, median, interquartile range, minimum and maximum) of total scores (SWBS) with religious connotation (RWB) and existential connotation (EWB), and Table 3 provides the classification of the related scores. Figure 1 shows the classification division of the questionnaire SWBS scores and Figure 2 Illustrates the distribution of the answers to the individual questions in the SWBS questionnaire.

\begin{tabular}{|c|c|c|c|c|c|c|c|c|c|}
\hline Score (pontos) & n & average & DP & median & \multicolumn{2}{|c|}{ IIQ } & mínimum & maximum \\
\hline Total (SWBS) & 28 & 113,4 & 6,0 & 115 & 110 & - & 118 & 97 & 120 \\
\hline Religious (RWB) & 28 & 59,1 & 1,8 & 60 & 59 & - & 60 & 55 \\
\hline Existential(EWB) & 28 & 54,4 & 5,5 & 56 & 50 & - & 59 & 39 \\
\hline
\end{tabular}




\begin{tabular}{|c|c|c|}
\hline $\begin{array}{c}\text { Score } \\
\text { classification }\end{array}$ & N & \% \\
\hline Total (SWBS) & 0 & $\mathbf{0}$ \\
\hline Low & 2 & $\mathbf{7 , 1}$ \\
\hline Moderate & 26 & $\mathbf{9 2 , 9}$ \\
\hline high & 0 & 0 \\
\hline Religious (RWB) & 0 & 0 \\
\hline low & 28 & 100 \\
\hline moderate & & \\
\hline high & 0 & 0 \\
\hline Existential (EWB) & 4 & 14,3 \\
\hline low & 24 & 85,7 \\
\hline moderate &
\end{tabular}

Table 3: Classification division of the questionnaire SWBS scores

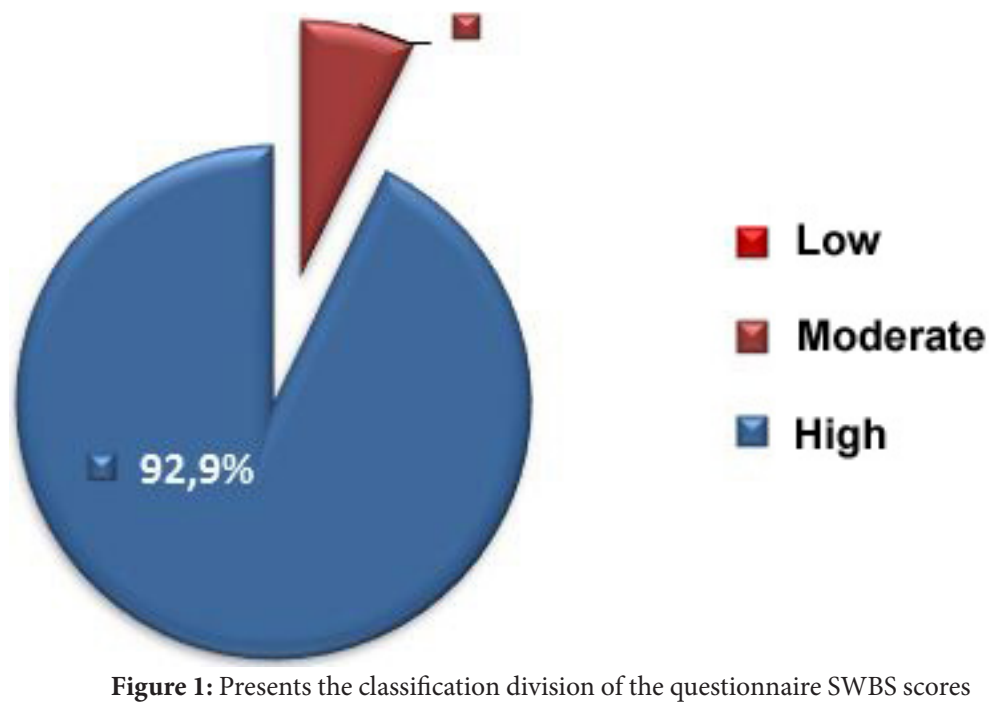

For reference purposes, table 4 provides the frequency (n) and percentage (\% of the line) of the answers according to the SWBS questionnaire.

\begin{tabular}{|c|c|c|c|c|c|c|c|c|c|c|c|c|c|}
\hline & \multirow{2}{*}{ Questions $\backslash$ Answers } & \multicolumn{2}{|c|}{ SA } & \multicolumn{2}{|c|}{ A } & \multicolumn{2}{|c|}{ PA } & \multicolumn{2}{|c|}{ PD } & \multicolumn{2}{|c|}{ D } & \multicolumn{2}{|c|}{ SD } \\
\hline & & $\mathrm{n}$ & $\%$ & $\mathrm{n}$ & $\%$ & $\mathrm{n}$ & $\%$ & $\mathrm{n}$ & $\%$ & $\mathrm{n}$ & $\%$ & $\mathrm{n}$ & $\%$ \\
\hline $\mathrm{P} 1$ & $\begin{array}{l}\text { I don't find fulfilling praying to God by } \\
\text { myself }\end{array}$ & 2 & 7,1 & 0 & 0 & 0 & 0 & 0 & 0 & 0 & 0 & 26 & 92,9 \\
\hline $\mathrm{P} 2$ & $\begin{array}{l}\text { I don't know who I am, where I come from } \\
\text { and where I'm going }\end{array}$ & 1 & 3,6 & 0 & 0 & 0 & 0 & 4 & 14,3 & 2 & 7,1 & 21 & 75,0 \\
\hline P3 & I believe God loves me and cares for me & 28 & 100 & 0 & 0 & 0 & 0 & 0 & 0 & 0 & 0 & 0 & 0 \\
\hline $\mathrm{P} 4$ & I see life as a positive experience & 26 & 92,9 & 1 & 3,6 & 1 & 3,6 & 0 & 0 & 0 & 0 & 0 & 0 \\
\hline P5 & $\begin{array}{l}\text { I believe God is impersonal and He does not } \\
\text { care for my every day issues }\end{array}$ & 1 & 3,6 & 0 & 0 & 0 & 0 & 0 & 0 & 0 & 0 & 27 & 96,4 \\
\hline P6 & I feel anxious about my future & 4 & 14,3 & 2 & 7,1 & 1 & 3,6 & 2 & 7,1 & 0 & 0 & 19 & 67,9 \\
\hline P7 & $\begin{array}{l}\text { I have a strong personal, relationship with } \\
\text { God }\end{array}$ & 27 & 96,4 & 0 & 0 & 1 & 3,6 & 0 & 0 & 0 & 0 & 0 & 0 \\
\hline P8 & I feel fulfilled and satisfied in life & 17 & 60,7 & 6 & 21,4 & 4 & 14,3 & 0 & 0 & 1 & 3,6 & 0 & 0 \\
\hline P9 & $\begin{array}{l}\text { I do not receive a lot of support and strength } \\
\text { from my God }\end{array}$ & 1 & 3,6 & 0 & 0 & 0 & 0 & 0 & 0 & 0 & 0 & 27 & 96,4 \\
\hline P10 & $\begin{array}{l}\text { I have a feeling of well-being about the } \\
\text { course my life is taking }\end{array}$ & 17 & 60,7 & 8 & 28,6 & 3 & 10,7 & 0 & 0 & 0 & 0 & 0 & 0 \\
\hline
\end{tabular}




\begin{tabular}{|c|c|c|c|c|c|c|c|c|c|c|c|c|c|}
\hline & \multirow{2}{*}{ Questions $\backslash$ Answers } & \multicolumn{2}{|c|}{ SA } & \multicolumn{2}{|c|}{ A } & \multicolumn{2}{|c|}{ PA } & \multicolumn{2}{|c|}{ PD } & \multicolumn{2}{|c|}{$\mathbf{D}$} & \multicolumn{2}{|c|}{ SD } \\
\hline & & $\mathrm{n}$ & $\%$ & $\mathrm{n}$ & $\%$ & $\mathrm{n}$ & $\%$ & $\mathrm{n}$ & $\%$ & $\mathrm{n}$ & $\%$ & $\mathrm{n}$ & $\%$ \\
\hline P11 & I believe God cares about my problems & 27 & 96,4 & 0 & 0 & 1 & 3,6 & 0 & 0 & 0 & 0 & 0 & 0 \\
\hline P12 & I don't care much for life & 1 & 3,6 & 0 & 0 & 1 & 3,6 & 1 & 3,6 & 0 & 0 & 25 & 89,3 \\
\hline P13 & $\begin{array}{l}\text { I don't have a fulfilling personal relationship } \\
\text { with God }\end{array}$ & 0 & 0 & 0 & 0 & 0 & 0 & 0 & 0 & 0 & 0 & 28 & 100 \\
\hline P14 & I feel good about in my future & 18 & 64,3 & 6 & 21,4 & 4 & 14,3 & 0 & 0 & 0 & 0 & 0 & 0 \\
\hline P15 & $\begin{array}{l}\text { My relationship with God makes me feel I'm } \\
\text { not alone }\end{array}$ & 28 & 100 & 0 & 0 & 0 & 0 & 0 & 0 & 0 & 0 & 0 & 0 \\
\hline P16 & I feel life is full of conflict and sadness & 4 & 14,3 & 2 & 7,1 & 1 & 3,6 & 4 & 14,3 & 2 & 7,1 & 15 & 53,6 \\
\hline P17 & $\begin{array}{l}\text { I feel fulfilled when I am in a close } \\
\text { communion with God }\end{array}$ & 27 & 96,4 & 0 & 0 & 1 & 3,6 & 0 & 0 & 0 & 0 & 0 & 0 \\
\hline $\mathrm{P} 18$ & Life makes no sense & 0 & 0 & 1 & 3,6 & 0 & 0 & 1 & 3,6 & 2 & 7,1 & 24 & 85,7 \\
\hline P19 & $\begin{array}{l}\text { My relationship with God helps my well- } \\
\text { being }\end{array}$ & 28 & 100 & 0 & 0 & 0 & 0 & 0 & 0 & 0 & 0 & 0 & 0 \\
\hline P20 & I believe there's a real purpose to my life & 28 & 100 & 0 & 0 & 0 & 0 & 0 & 0 & 0 & 0 & 0 & 0 \\
\hline & strongly agree (SA), agree (A), partly agree (P) & $\mathrm{pa}$ & dis & & ), & & ), & & oly & & D) & & \\
\hline
\end{tabular}

Table 4: Answer distribution based on the SWBS questions

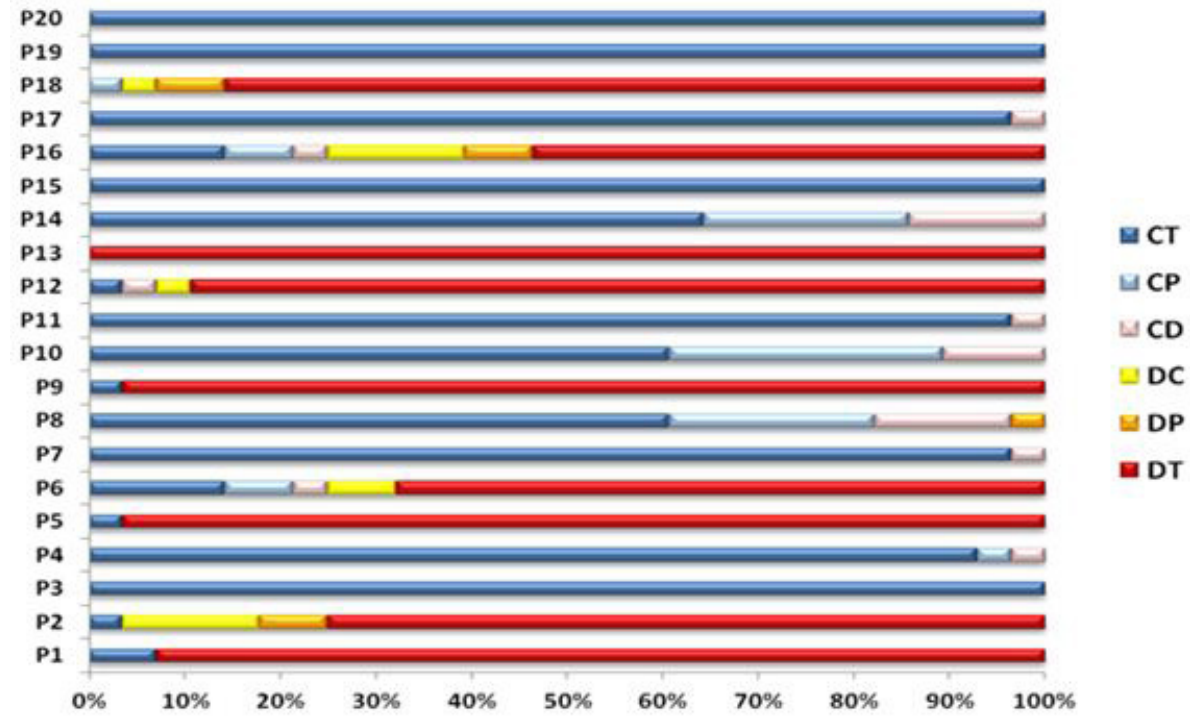

Figure 2: Illustrates the distribution of the answers to the individual questions in the SWBS questionnaire

\section{Description of the researcher's questionnaire}

Tables 5, 6 and 7 provide the distribution of the answers to researcher's questionnaire, addressing the aspects of faith/religiosity, reaction to diagnosis/adherence to treatment and perspective of treatment's outcome, respectively.

\begin{tabular}{|l|c|c|}
\hline Questions about the Faith and Religiosity & $\mathbf{n}$ & $\mathbf{\%}$ \\
\hline 1. Do you consider yourself a religious person? & & \\
\hline Yes & 28 & 100 \\
\hline No & 0 & 0 \\
\hline 2. How religious you would say you are? & & \\
\hline Not much & 2 & 7,1 \\
\hline Moderately & 5 & 17,9 \\
\hline Very & 21 & 75,0 \\
\hline $\begin{array}{l}\text { 3. How strongly do you believe that God is the main source } \\
\text { of your strength while fighting the breast cancer? }\end{array}$ & & \\
\hline Not much & 0 & 0 \\
\hline Moderately & 0 & 0 \\
\hline
\end{tabular}




\begin{tabular}{|c|c|c|}
\hline Questions about the Faith and Religiosity & $\mathbf{n}$ & $\%$ \\
\hline Very & 28 & 100 \\
\hline \multicolumn{3}{|l|}{ 4. Do you consider yourself spiritual person? } \\
\hline Yes & 28 & 100 \\
\hline No & 0 & 0 \\
\hline \multicolumn{3}{|l|}{ 5. Do you consider yourself a religious person? } \\
\hline Yes & 24 & 85,7 \\
\hline No & 4 & 14,3 \\
\hline \multicolumn{3}{|l|}{ 6. Do you practice any religion? } \\
\hline Yes & 26 & 92,9 \\
\hline No & 2 & 7,1 \\
\hline \multicolumn{3}{|l|}{ 7. What is your religion? } \\
\hline Evangelic & 13 & 46,4 \\
\hline Catholic & 10 & 35,7 \\
\hline Jehovah's whiteness & 2 & 7,1 \\
\hline Spirit & 2 & 7,1 \\
\hline None & 1 & 3,6 \\
\hline \multicolumn{3}{|l|}{$\begin{array}{l}\text { 8. How often do you practice your religion in group? } \\
\text { (church, temple, religious center)? }\end{array}$} \\
\hline Rarely & 11 & 39,3 \\
\hline Moderately & 7 & 25,0 \\
\hline Always & 10 & 35,7 \\
\hline \multicolumn{3}{|l|}{$\begin{array}{l}\text { 9. How often do you practice your religion by yourself? (talk } \\
\text { to God, read the Bible or other religious material, listen to } \\
\text { the radio shows or watch TV shows) }\end{array}$} \\
\hline Rarely & 0 & 0 \\
\hline Moderately & 2 & 7,1 \\
\hline Always & 26 & 92,9 \\
\hline \multicolumn{3}{|l|}{$\begin{array}{l}\text { 10. How important is the religion for you right now, when } \\
\text { dealing with the stress? }\end{array}$} \\
\hline Not much & 0 & 0 \\
\hline Moderately & 0 & 0 \\
\hline Very important & 28 & 100 \\
\hline
\end{tabular}

Table 5: Distribution of answers to questions of faith and religiosity

\begin{tabular}{|l|c|c|}
\hline Questions about the reaction to diagnosis and adherence to treatment & $\mathbf{n}$ & $\%$ \\
\hline 1. Did you think about the God when you've received the diagnosis? & & \\
\hline Yes & 28 & 100 \\
\hline No & 0 & 0 \\
\hline 2. Do you believe that faith is the key to finding the cure? & 28 & 100 \\
\hline Yes & 0 & 0 \\
\hline No & & \\
\hline 3. Did you, at any point, see this diagnosis as the punishment? & 3 & 10,7 \\
\hline Yes & 25 & 89,3 \\
\hline No & & \\
\hline $\begin{array}{l}\text { 4. Do you find comfort, strength and dedication to the treatment in the } \\
\text { faith and religiosity? }\end{array}$ & 28 & 100 \\
\hline Yes & 0 & 0 \\
\hline Moderately & 0 & 0 \\
\hline No & & \\
\hline
\end{tabular}




\begin{tabular}{|l|c|c|}
\hline Questions about the reaction to diagnosis and adherence to treatment & $\mathbf{n}$ & $\%$ \\
\hline 5. Have you adhered to the treatment so far? & 27 & 96,4 \\
\hline Yes & 1 & 3,6 \\
\hline Moderately & 0 & 0 \\
\hline No & & \\
\hline 6. How much your spirituality/ religiosity assists in your treatment? & 28 & 100 \\
\hline Very & 0 & 0 \\
\hline Moderately & 0 & 0 \\
\hline None & & \\
\hline $\begin{array}{l}\text { 7. Do you find it important that doctors include your religion in your } \\
\text { treatment at some point? (a short prayer, reading of a short paragraph } \\
\text { from the Bible, a short moment of reflection) }\end{array}$ & 19 & 67,9 \\
\hline Yes & 9 & 32,1 \\
\hline No & & \\
\hline $\begin{array}{l}\text { 8. Do you have any beliefs that might interfere with the medical } \\
\text { treatment? }\end{array}$ & 2 & 7,1 \\
\hline Yes & 26 & 92,9 \\
\hline No & & \\
\hline
\end{tabular}

\begin{tabular}{|c|c|c|c|c|c|c|c|c|c|c|}
\hline Questions about the perspective on the outcome & \multicolumn{2}{|c|}{$\mathbf{n}$} & \multicolumn{2}{|r|}{$\%$} & & & & & & \\
\hline \multicolumn{11}{|l|}{$\begin{array}{l}\text { 1. How much do you believe that the outcome of } \\
\text { your treatment will be positive? }\end{array}$} \\
\hline Not much & & 1 & \multicolumn{2}{|r|}{3,6} & & & & & & \\
\hline Moderately & & 6 & \multicolumn{2}{|r|}{21,4} & & & & & & \\
\hline Very & & 21 & \multicolumn{2}{|r|}{75,0} & & & & & & \\
\hline \multicolumn{11}{|l|}{ 2. How do you see your future after the treatment? } \\
\hline Not good & & 0 & \multicolumn{2}{|r|}{0} & & & & & & \\
\hline Uncertain & & 4 & \multicolumn{2}{|r|}{14,3} & & & & & & \\
\hline Good & \multicolumn{2}{|r|}{24} & \multicolumn{2}{|r|}{85,7} & & & & & & \\
\hline $\begin{array}{l}\text { 3. Put in order from } 1 \text { to } 5 \text { the following items } \\
\text { according to their importance in your recovery: }\end{array}$ & \multicolumn{2}{|c|}{$\begin{array}{l}1^{\circ} \\
\text { Place }\end{array}$} & \multicolumn{2}{|c|}{$\begin{array}{l}2^{\circ} \\
\text { Place }\end{array}$} & \multicolumn{2}{|c|}{$\begin{array}{c}3^{\circ} \\
\text { Place }\end{array}$} & \multicolumn{2}{|c|}{$\begin{array}{c}4^{\circ} \\
\text { Place }\end{array}$} & \multicolumn{2}{|c|}{$\begin{array}{l}5^{\circ} \\
\text { Place }\end{array}$} \\
\hline 3.a) spirituality & 28 & 100 & 0 & 0 & 0 & 0 & 0 & 0 & 0 & 0 \\
\hline 3.b) religion & 0 & 0 & 4 & 14,3 & 2 & 7,1 & 20 & 71,4 & 2 & 7,1 \\
\hline 3.c) medical team & 0 & 0 & 13 & 46,4 & 12 & 42,9 & 3 & 10,7 & 0 & 0 \\
\hline 3.d) family & 0 & 0 & 10 & 35,7 & 14 & 50,0 & 3 & 10,7 & 1 & 3,6 \\
\hline 3.e) friends & 0 & 0 & 1 & 3,6 & 0 & 0 & 2 & 7,1 & 25 & 89,3 \\
\hline
\end{tabular}

Table 7: Answer distribution on the questions about the perspective on the outcome of the treatment

The results of the analysis confirm the influence of faith as a coping strategy for breast cancer. It is noted that $100 \%$ of the population in the sample group consider having faith in God, regardless of whether or not they have a religion. They believe that God is the main force that sustains and drives them in coping with cancer. They believe that having faith is the paramount in healing and that their spirituality/religiosity are sources of comfort, strength and determination during the treatment. This creates greater confidence in a positive outcome in terms of the treatment results and their future.

In the light of the research carried out on the subject, the positive effects of the inclusion of spirituality in the clinical treatment of breast cancer are undeniable. Faith and religious beliefs present themselves with great potential to positively influence the impact of negative emotions and stress on the patient, reflecting directly on their physical and mental health. That is, the connection between patients' faith and the religiosity with their health and well-being is well-known.

As Koening points out [6]: "Learning to respect the power of these beliefs and use them to accelerate healing and full recovery of the patient should be a priority for medicine and modern medical care." According to him, even if the patient's religious involvement had no relation to his physical health, the inclusion of spirituality into clinical treatment should be prioritized, considering that many patients are evidently comfortable with their religious beliefs and practices. 
Regarding this issue, the present study indicates that $67.9 \%$ of respondents consider important that their faith/religiosity be incorporated into the treatment by a member of the medical team, for example, through a brief prayer, reading a short excerpt from the Bible or brief moment of reflection. For these patients, such a practice would bring comfort and well-being to the routine of the treatment, strengthening a positive look in coping with the disease.

When it comes to religious doctrines that could confront medical decisions, only $7.1 \%$ of the patients interviewed said that they had spiritual conflicts about this aspect. All of them exemplified the possibility of a blood transfusion as a point of confrontation, which restricts the subject to very specific cases.

Another relevant aspect that reinforces faith as a coping tool was the question that asks from the interviewee to list out the things that most influence him or her to achieve treatment success. Again, 100\% listed faith as the first thing on their list of importance.

As for the questionnaire applied to spiritual well-being (SWBS), the general average reached score was $92.9 \%$. The analysis of the data surveyed by the religious welfare sub-scale (RWB) reached a surprising $100 \%$ score among the interviewees. On the other hand, the analysis of the existential welfare subscale (EWB) reached the $85.7 \%$ score, also resulting in a high satisfaction index, in relation to the patient's positive expectation regarding the future, optimism and feeling of purpose in life.

\section{The final arguments}

The current study presented in this article reaffirms the influence of faith and religiosity in coping with difficult and stressful situations, among them, breast cancer. It demonstrates how religious beliefs and spirituality present themselves as the most potent and active forces in the patient's life, with evident effects of profound changes in their personal experiences and social behavior, positively reflecting their spiritual and existential well-being and in the patient's treatment of the disease and its direct and indirect consequences.

The participating patients in this study affirm that it was only through faith and their religious practices that acceptance of the diagnosis was easier, the effective adherence to the treatment with positive perspectives to recover and to come to a positive outcome for their lives are the most relevant factors pointed out by this study.

Thus, it is possible to conclude that, even though it is improbable to determine the mechanisms in which spirituality influences health, the strong and undeniable influence of faith and religiosity in coping with the breast cancer has been shown.

\section{References}

1. Silva, Luiz Antonio Santini (2016) Oncologic surgery: a great challenge. Rev Col Bras Cir 43: 139-40.

2. Nazário ACP, Kemp C. Câncer de mama (2007) Diagnosis and treatment. Barueri, São Paulo: Editora Manole; 2007.

3. Hill PC, Pargament KI (2003) Advances in the conceptualization and measurement of religion and spirituality: Implications for physical and mental health research. American Psychologist 58: 64-74.

4. Pargament KI (1997) The Psychology of religion and coping. Theory, research, practice. New York: The Guilford Press.

5. Astrow BA (2009) Approaching the spiritual and religious concerns of the patient with cancer: Creating an environment for dialogue regarding spiritual concerns. Maimonides Cancer Center, NY.

6. Koening, Harold G (2015) Medicine, religion and health: the meeting of science and spirituality; translation of Iuri Abreu. Porto Alegre, RS-L \& PM.

7. Lwanga SK, Lemeshow S (1991) Sample size determination in health studies: a practical manual. Geneva, World Health Organization.

8. Paloutzian R, Ellison C (1982) Loneliness, spiritual well-being and the quality of life. In: Peplau D, Perlman D. Loneliness: a sourcebook of current theory, research and therapy. New York: John Wiley and Sons.

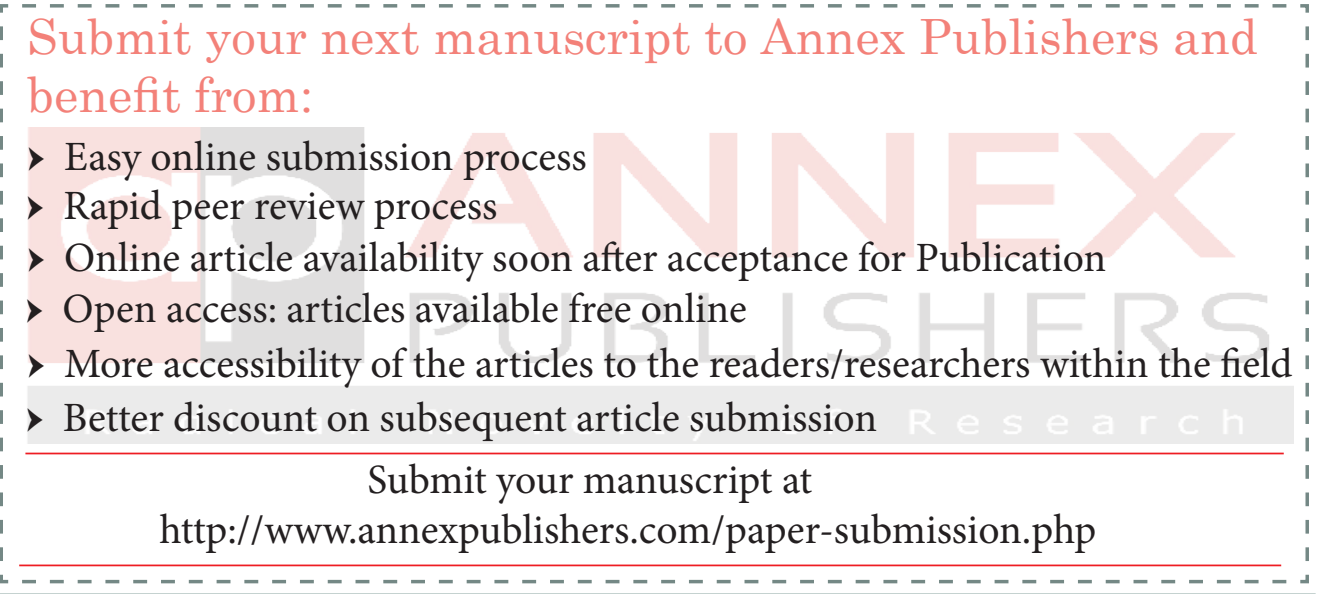


